\title{
Degradation and Human Health Risk Assessment of Underground Water of Trans Ganga-Yamuna Rural Regions of A North Indian district
}

\author{
Ayesha Mariya ${ }^{1}$, K.P. Singh ${ }^{2 *}$, Ashutosh Tripathi ${ }^{1 *}$, Mohd Masood ${ }^{1}$, Niraj Kumar ${ }^{3}$ \\ ${ }^{1}$ The Institute of Applied Sciences, Allahabad, India \\ ${ }^{2}$ Department of Zoology, University of Allahabad, Allahabad, India \\ ${ }^{3}$ The National Academy of Sciences, India, Allahabad
}

Received: 3 November, 2016; Accepted: 23 November, 2016 ; Published: 3 December, 2016

*Corresponding author: K. P. Singh, Associate Professor, Department of Zoology, University of Allahabad, Allahabad, India, Tel: +91 9414309681; E-mail: kpsald29@gmail.com

Ashutosh Tripathi, Ph.D. Research Associate, The Institute of Applied Sciences, Allahabad, India, Tel: +91 9336965144; E-mail: ashu.evs@gmail.com

\begin{abstract}
The present study investigates the physico-chemical qualities and fecal contamination of ground water; and related health risks of rural areas of trans-Ganga and Yamuna region of a North-Indian district, Allahabad, India. The $\mathrm{pH}$, turbidity, TDS, BOD, and COD, total alkalinity, total hardness, chloride and fecal coliform contamination was estimated in 269 water samples of 14 villages. Higher levels of turbidity, alkalinity, chloride and fecal contamination in ground water of trans-Yamuna area were found as compared to trans-Ganga. About 75\% samples of trans-Yamuna were contaminated with faecal coliform as compared to trans-Ganga region (55\%).Significant positive correlation existed between chloride, TDS, alkalinity $(r=0.74$ $0.91 ; p<0.05)$, hardness and $\mathrm{pH}(r=0.75-0.85 ; p<0.05)$. The Relative Risk (RR) of some waterborne diseases was very high (2.11-8.00) in trans-Yamuna as compared to trans-Ganga region (1.81-3.48). Furthermore, the new treatment requirement parameter (NNT) for waterborne diseases of these rural areas was also estimated, which suggests that the need of a new and improved treatment approach for these diseases is more frequent in the trans-Yamuna area as compared to trans-Ganga. Our results suggest urgent attention and intervention for improving the quality of potable water in these rural areas and to control the waterborne diseases associated to rural health risks.
\end{abstract}

Keywords: Underground water; Drinking water contamination; waterborne diseases; Health effects; Risk assessment

\section{Introduction}

Water is of great importance in the maintenance of health of plants, animals and human beings [1]. Due to burden of population and its wasteful activities; tremendous pressure is being exerted on the quantity and quality of this scanty resource. Various domestic as well as industrial activities are contaminating not only the soils and surface water but also underground water sources over the globe [2,3]. The ground water is normally considered safe for drinking purposes in comparison to other sources of water as contaminated water coming as run off can directly get mixed with the surface water and may pollute it however the same water cannot directly pollute the below ground water as soil in many profiles act as the filter and many unwanted contaminant get fixed in soil only [4, 5]. However, the anthropogenic activities such as extensive use of fertilizers, pesticides, insecticides, and industrial waste and other activities, may directly or indirectly affect the quality of ground water, since these contaminants may ultimately find way to the ground water during and after the monsoon season through open wells and creeks of the rock and through other hydro-geological processes $[6,7,8]$. For example, a well is located near land that is used for farming where certain kinds of chemicals are applied to crops or near a gas station and leakage form storage tank and septic tanks and/or waste-disposal sites also can contaminate groundwater. The quality of the groundwater can be determined only after analyzing its physico-chemical characteristics $[9,10]$. Although rural areas are regarded as less polluted however, anthropogenic activities and unhygienic waste disposal systems of rural areas are contaminating drinking water systems at this time $[11,12]$.

The microbial and chemical contamination of groundwater is caused by both point sources of pollution (i.e. mixing of domestic waste waters) and non-point sources of pollution (e.g. sewage leakage and overflow, animal and human excreta mixing in runoff and agricultural runoffs) $[13,14,15]$. The water quality is also dependent on storm events, evaporation, catchment characteristics, and land use and population density of the area [16]. The water related management problems such as drainage infrastructure, sewer overflows, unmanaged septic tanks and other sanitation related unhealthy infrastructure and practices also contaminate water and spread diseases [17]. Unlike to urban centers, fecal contamination frequently from livestock 
and inadequate on-site human waste disposal systems is one of the major concerns in many rural areas [18]. The distinct morphological, physical and biological characteristics set them apart from other contaminants that are transported in surface and subsurface water environments [19]. This kind of contamination is dispersed sporadically and is influenced by a range of interacting environmental factors, hence assessing a point or non-point source of this is a big problem which hinders its proper eradication [18]. Therefore, it becomes very much important to detect faecal contamination in groundwater and associated health affects, because most of the rural areas don't have basic water treatment facilities [20]. Failure to provide adequate protection, effective treatment and disinfection of drinking water in such rural areas will expose the rural communities to the risk of outbreaks of intestinal and other infectious diseases $[18,20]$.

The Gangetic plains of North India are one of the most fertile zones of the world, hence human habitation and related activities are increasing day by day and the increasing population is degrading the environment [21]. Many anthropogenic activities along the course of river Ganges and Yamuna are directly and indirectly polluting the surface as well as ground waters [16, 22]. As these rural areas have unmanaged sanitation and drinking water supply system the people are always on the verge of infections arising out due to consumption of contaminated water [16]. The present study was undertaken to compare the water quality of the underground water of two distinct rural areas (one each from Trans Ganga-Yamuna Rivers) of Allahabad district of the Northern India (Figure 1). The study aims to assess the quality and its degradation in underground water of some rural areas of this region and its relative risks in terms of health in human populations exposed to such water qualities. The findings serve as baseline data for these areas and can be used for future scientific research as well as water management measures to enhance the quality of these water sources and related health issues.

\section{Materials and Method}

\section{Study areas}

The study was conducted in the Allahabad district of Uttar Pradesh, India in two blocks namely Shankargarh and Phulpur (Figure 1). The Shankargarh block is situated Trans to Yamuna river and Phulpur is situated Trans to Ganga River. Ganga and Yamuna are the two main rivers that along with a number of tributaries transport a large amount of silt, clay and sand in the basin which are directly deposited at the time of flood. The flood plain deposits are developed at the constructive side of river channels. The rivers are good zones for groundwater recharge. The Ganga and the Yamuna rivers change their courses over a period of time, hence palaeo-channels are formed which are good source of underground water [16]. The river channels are also responsible to bring-up a high amount of diffuse pollutants from upstream areas [23].

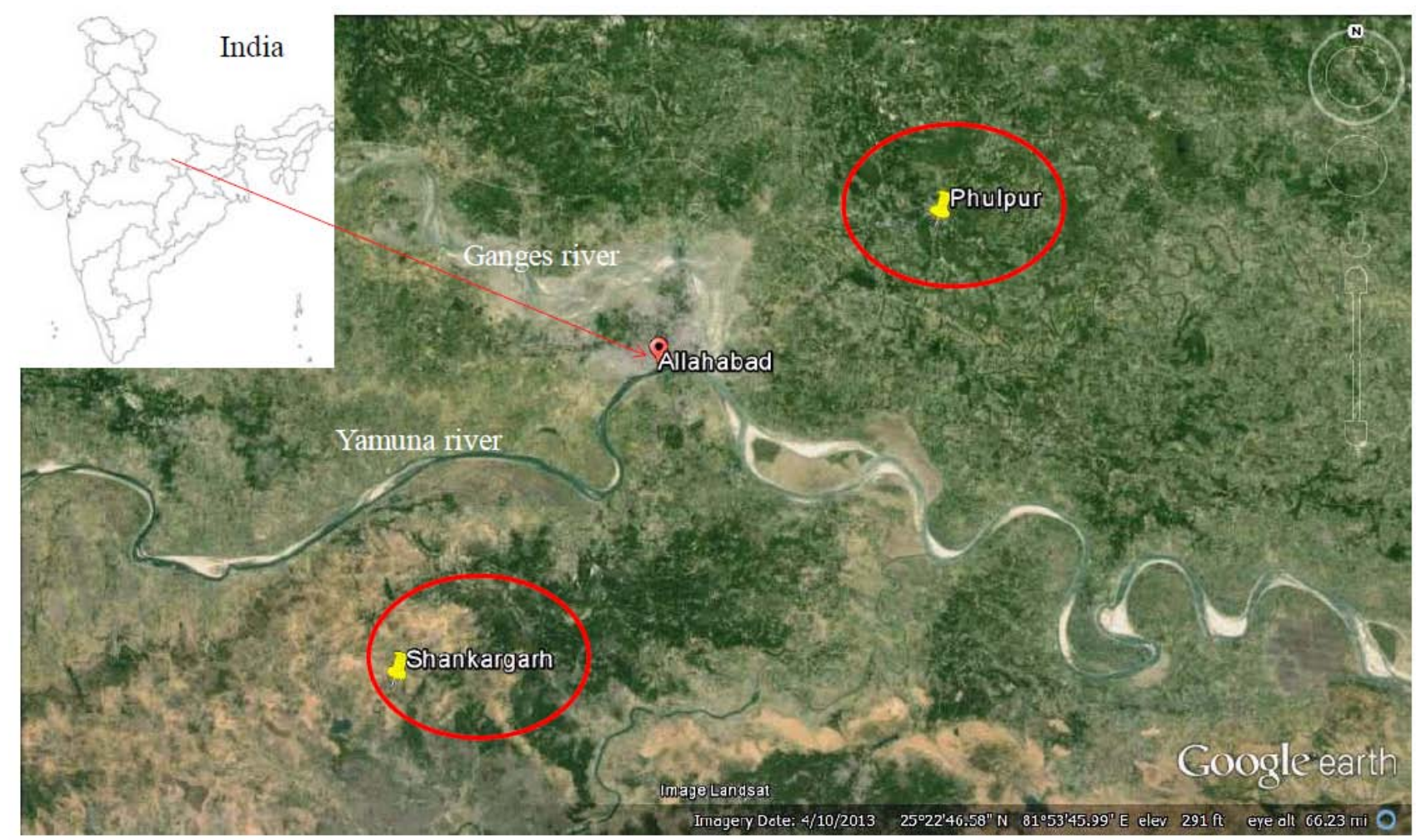

Source: Google earth satellite image

Figure 1: locations of the water sampling areas (Phulpur and Shankargarh) in Allahabad district 
The Shankargarh block is situated $45 \mathrm{~km}$ southwest of Allahabad city. Geologically, this area comprises of Upper Vindhayan formations consisting of mainly sandstone and shale. The area shows a nearly flat to a gently undulated topography with small hillocks and rolling topography and soils are formed by disintegration and weathering [24]. The Phulpur block is situated $25 \mathrm{~km}$ north to Allahabad city. This area comprises of very fertile alluvial soil. Geological status and vegetation of both the areas are distinct from each other; Shankargarh has rocky terrain and less vegetation, whereas Phulpur has good grassland vegetation and agricultural fields (Figure 1) [24]. Therefore, the anthropogenic practices also vary with geographical dissimilarities in these two selected areas.

\section{Collection of water samples and analysis}

In order to better understand the physico-chemical and microbial contamination in these two areas water sampling was conducted in a cluster of villages. Eight (8) villages from the Shankargarh area and six (6) villages from Phulpur area (in 27 villages of the sampling block) were selected randomly for the collection of water samples and health study (Table 1). Almost all possible sources of groundwater used for drinking purposes (hand pump sources) in the selected villages were sampled, thus a total of 269 samples were collected from both the areas (Table 1). The samples were collected in triplicate and in adequate amount in pre washed sample containers, packed carefully and transported immediately to the lab for further tests. The $\mathrm{pH}$ and Total Dissolved Solids (TDS) were measured immediately with the help of field kit (HANNA- HI98129), while Turbidity, Alkalinity, Hardness, Chloride, Biochemical Oxygen Demand (BOD), and Chemical Oxygen Demand (COD) were estimated in water samples as per standard procedures prescribed by APHA [25]. Faecal coliform concentration was calculated following the Membrane Filtration Method of USEPA (No. 8074) [26].

\section{Health survey}

Secondary information for some waterborne diseases was obtained from the government's primary health care facility (Primary Healthcare Center known as PHC) of both the areas. In

Table 1: Number of samples collected from different villages of Shankargarh (trans-Yamuna) and Phulpur (trans-Ganga) areas.

\begin{tabular}{|l|l|l|l|l|}
\hline S. No. & Trans-Yamuna (Shankargarh) & \multicolumn{2}{|c|}{ Trans-Ganga (Phulpur) } \\
\hline & Sampling Location & $\begin{array}{l}\text { Number of } \\
\text { samples } \\
\text { collected }\end{array}$ & $\begin{array}{l}\text { Sampling } \\
\text { Location }\end{array}$ & $\begin{array}{l}\text { Number of } \\
\text { samples } \\
\text { collected }\end{array}$ \\
\hline $\mathbf{1}$ & Pavari & 20 & Basmahua & 30 \\
\hline $\mathbf{2}$ & Lohgara & 19 & Semri & 19 \\
\hline $\mathbf{3}$ & Hanuman Nagar & 19 & Ramnathpatti & 12 \\
\hline $\mathbf{4}$ & Nibi & 10 & Gram Aata & 22 \\
\hline $\mathbf{5}$ & Bara Tehseel & 22 & Munshikhvurd & 7 \\
\hline $\mathbf{6}$ & Lohgara Khas & 27 & Jafarpur & 28 \\
\hline $\mathbf{7}$ & Chandra & 17 & & \\
\hline $\mathbf{8}$ & Gurme Bara & 17 & & \\
\hline & & & & \\
\hline
\end{tabular}

these areas these PHCs are the only health care centers which provide medical facilities to the nearby rural people and due to this fact the secondary data were taken from these centers as representative information of health status of these areas. For primary data collection, a health survey was conducted in the local residents of each selected village. In this survey, 100 respondents from Shankargarh and 80 from Phulpur areas were randomly selected, and individuals reliant on selected water sources for sampling and suffering from any waterborne disease were taken into account during study period. In contrast, 50 respondents were also selected in the urban areas of these blocks having safe access to water and were treated as control subjects.

\section{Statistical analysis}

Mean and Standard Error of Mean were calculated for each water quality parameter. Independent student's t-test was used to understand the significance of the difference among the concentrations of water quality parameters at different sampling locations. Pearson's correlation coefficient ( $\mathrm{r}$ ) was used to understand the relationship between various water quality parameters at each sampling area. The level of significance was set at $p<0.05$. The Relative Risk (RR), its standard error and 95\% confidence interval were calculated according to Altman [27].The relative risk or risk ratio was calculated by following formula:

$$
R R=\frac{a /(a+b)}{c /(c+d)}
$$

Where, RR is relative risk, $\mathrm{a}$ and $\mathrm{b}$ are the number with positive (bad) outcome and negative (good) outcome respectively in the populations exposed to contaminated water while $\mathrm{c}$ and $\mathrm{d}$ are the number with positive (bad) and negative (good) outcomes in control populations. Z-stat and the number needed to treat (NNT) which is the estimated number of patients who need to be treated with the new treatment rather than the standard treatment (or no treatment) for one additional patient to benefit was also calculated following Altman [28]. Origin-8pro and Sigmaplot-10 software packages were used for statistical analysis and preparation of graphical representations.

\section{Results}

\section{Groundwater quality of trans-Yamuna area (Shankargarh)}

The range, mean, and 25-75 percentile of the water quality of ground water samples of Shankargarh area are given in [Figure $2 \mathrm{~A}]$. The $\mathrm{pH}$ ranged from $7.17 \pm 0.22$ to $7.57 \pm 0.25$ with the maximum being in Pavari village. TDS ranged from $279.33 \pm 9.45$ to $509.29 \pm 15.2 \mathrm{mg} \mathrm{L}^{-1}$ and it was maximum in Gurme Bara village, whereas turbidity was maximum in Hanuman Nagar which ranged from $1.57 \pm 0.05$ to $22.66 \pm 0.7 \mathrm{mg} \mathrm{L}^{-1}$. The BOD $(1.07 \pm$ 0.02 to $\left.1.75 \pm 0.06 \mathrm{mg} \mathrm{L}^{-1}\right)$ and COD (3.10 \pm 0.12 to $5.74 \pm 0.16$ $\mathrm{mg} \mathrm{L}^{-1}$ ) range was not higher as compared to other parameters and according to Bureau of Indian Standards (BIS, 1991) [29]. Both of these indices were higher in Lohgara village. Bicarbonate and Hardness ranged from $148.06 \pm 5.56$ to $710.46 \pm 21.2 \mathrm{mg} \mathrm{L}^{-1}$ and $209.39 \pm 6.5$ to $909.49 \pm 26.89 \mathrm{mg} \mathrm{L}^{-1}$ respectively, and both were found maximum in Gurme Bara. The Chloride content was 
recorded maximum in Bara tehseel. According to BIS: 1991 standards [29] laid down in India for potable water, $\mathrm{pH}$ was in normal range however TDS values were greater in one village and three other were close to this. Notably, water samples of $6(75 \%)$ out of 8 villages were highly turbid according to these standards. The BOD and COD of water samples of all villages were normal. Water samples of 7 villages showed high alkalinity above than normal while hardness was in normal range except of three villages (Bara tehsil, Chandra and Gurme Bara). Chloride content was high above than normal in 6 villages of this area.

In this area, about $75 \%$ underground water samples demonstrated the presence of faecal coliform (Figure $3 \mathrm{~A}$ ) and $100 \%$ water samples of Nibi village were found positive for coliform infection.

\section{Groundwater quality of Phulpur block}

The range, mean, and 25 - 75 percentile of the water quality of ground water samples of Phulpur area are given in [Figure 2B]. In this area, $\mathrm{pH}$ ranged from $7.26 \pm 0.21$ to $7.76 \pm 0.23$ while TDS
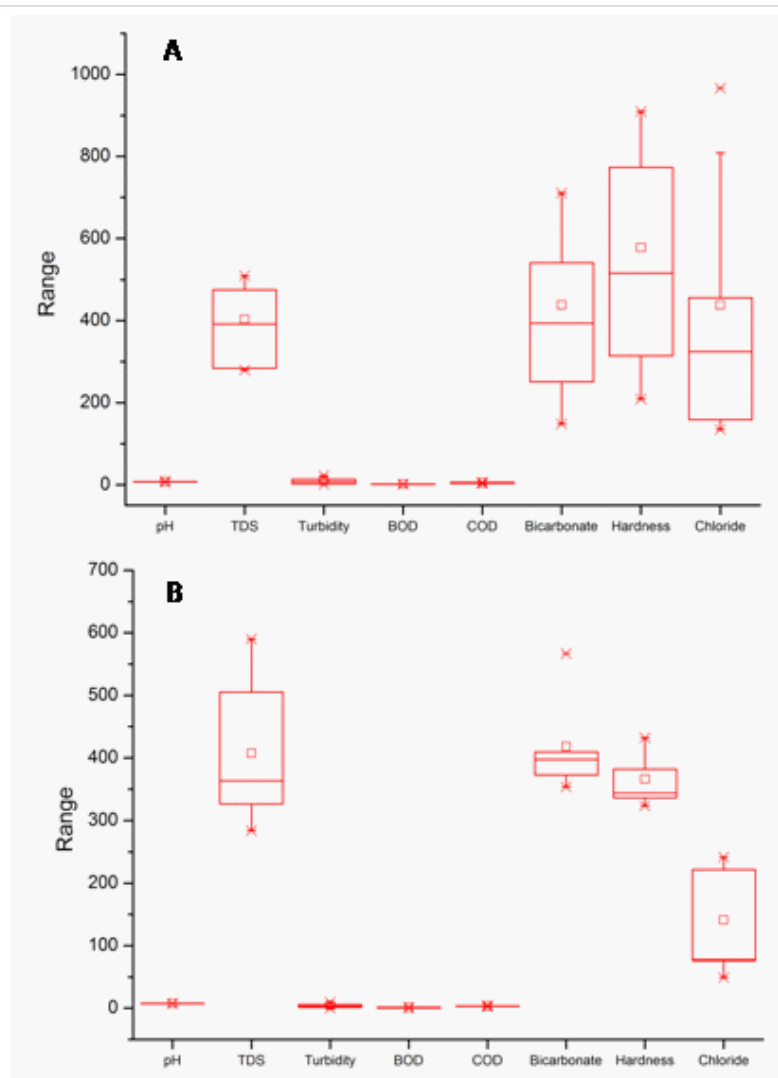

Figure 2: Box chart showing mean, range, and percentiles with minimum and maximum of selected water quality parameters of different villages of the selected sampling areas; A: Shankargarh, B: Phulpur. (The boxes show first and third quartiles while whiskers show 5-95\% intervals. The line in the boxes represents the median, and the small boxes, the mean value). [Prescribed limits of Bureau of Indian Standards-1991: pH-6.5-8.5; TDS-500 (mg L-1); Turbidity-5.0 NTU; BOD-1.0 (mg L $\left.{ }^{-1}\right)$; COD-8.0 (mg L $\left.{ }^{-1}\right)$; Bicarbonate-200 (mg L $\left.{ }^{-1}\right)$; Hardness-300-600 (mg $\left.\mathrm{L}^{-1}\right)$; Chloride-250 (mg L$\left.{ }^{-1}\right)$.
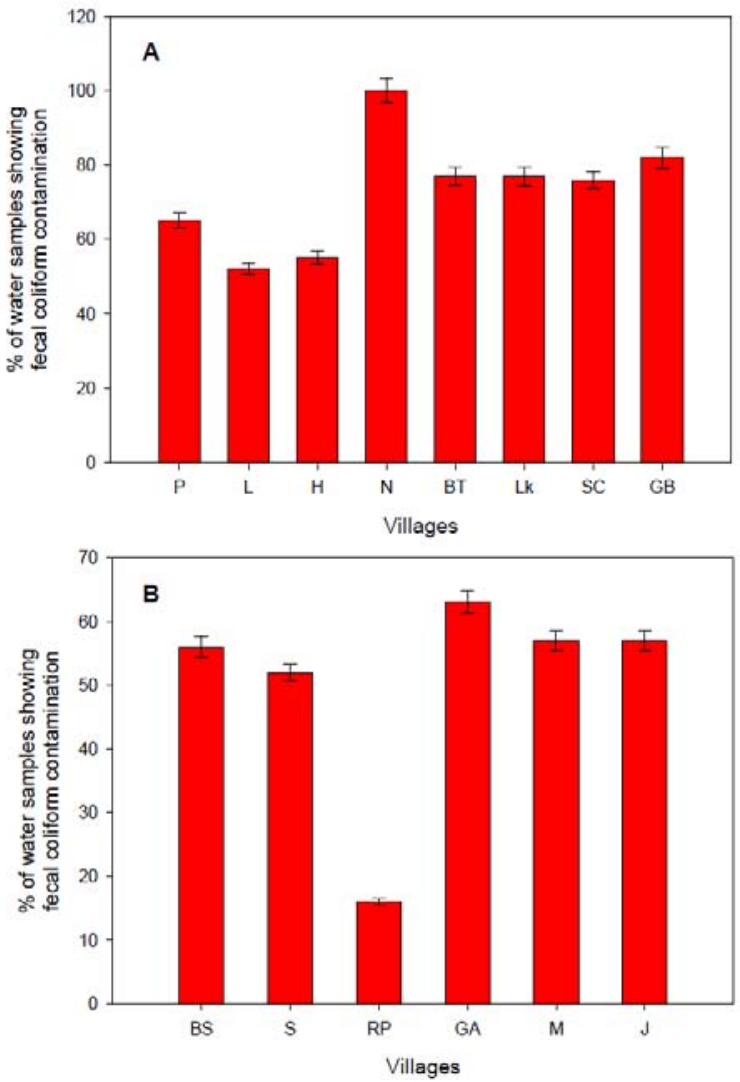

Figure 3: Percentage of water samples in different villages of the sampling area showing faecal coliform contamination. A: Shankargarh; B: Phulpur. (On $\mathrm{x}$ axis names of the villages of both the sampling areas (Table 1) are in their short forms).

ranged from $284.14 \pm 9.2$ to $590.00 \pm 18.6 \mathrm{mg} \mathrm{L}^{-1}$, and both were recorded maximum in Basmahua village. Turbidity was maximum in Gram Aata ranging from 0 to $10 \pm 0.34 \mathrm{mg} \mathrm{L}^{-1}$. BOD and COD values ranged from $0.45 \pm 0.018$ to $1.27 \pm 0.05 \mathrm{mg} \mathrm{L}^{-1}$ and 2.79 \pm 0.05 to $4.21 \pm 0.07 \mathrm{mg} \mathrm{L}^{-1}$, and these were found maximum in Jafarpur and Munshikhurd villages respectively. Bicarbonate alkalinity was highest in Gram Aata and ranged from $353.45 \pm$ 13.2 to $566.911 \pm 18.5 \mathrm{mg} \mathrm{L}^{-1}$. Hardness ranged from $323.61 \pm$ 9.5 to $431.85 \pm 15.1 \mathrm{mg} \mathrm{L}^{-1}$ while chloride ranged from $48.82 \pm$ 1.8 to $241.73 \pm 8.6 \mathrm{mg} \mathrm{L}^{-1}$ in water samples. According to BIS: 1991 [29] standards laid down in India for potable water, $\mathrm{pH}$ was within the range, whereas TDS value was above the BIS standard in two villages only, out of six villages selected. $50 \%$ village water samples were turbid (above than normal) according to these standards. The BOD and COD were within the range. It was interesting to note that the ground water samples of all villages (100\%) showed high alkalinity above the permissible limit while hardness was in normal range in all sampling locations. Chloride content was also in normal range in all sampling locations in this area. In this region, approximately 55\% ground water samples were found to be positive for faecal coliform test (Figure 3B), and the maximum fecal contamination in samples was found in Aata village (62\%). 
Pearson's correlation coefficient ( $\mathrm{r}$ ) between water quality variable was calculated in each sampling area (Table 2 and 3). In Shankargarh area (Table 2), Chloride contents were positively correlated with the TDS, alkalinity and hardness $(r=0.74-0.91 ; p$ $<0.05)$ indicating the same source of all these contaminations. Hardness was positively correlated with the $\mathrm{pH}$, TDS and alkalinity ( $r=0.75-0.85 ; p<0.05$ ) while $\mathrm{pH}$ was negatively correlated with the turbidity $(r=0.72 ; p<0.05)$. However in Phulpur area (Table 3), fewer correlations were observed as compared to Shankargarh area. Here turbidity was positively correlated with the chloride, alkalinity and BOD ( $r=0.75-0.87$; $p<0.05$ ) while COD was positively correlated with chloride ( $r=$ $0.82 ; p<0.05)$.

\section{Health effects of the degraded water qualities}

Secondary information sources revealed that waterborne diseases in the Shankargarh area were more prevalent as compared to Phulpur area (Table 4). Monthly average cases of diarrhoea, dysentery, jaundice, and other Gastroenteritis (GI) disorders (abdominal pain, colitis, liver inflammations and vomiting etc) were higher in Shankargarh area as compared to Phulpur region. There was around 27\% fewer occurrences of diseases reported in Phulpur as compared to Shankargarh. This indicates that the waterborne diseases were more prevalent in Shankargarh area (trans-Yamuna). As secondary health findings cannot be directly related to the water sources sampled on an individual, primary survey on health status were obtained by a questionnaire survey.

Relative risks were calculated to understand the risks arising out of the particular waterborne disease (Table 5). RR was in the order to $8.00>4.57>3.11>2.11$ in Shankargarh, and it was found in order of $3.48>2.45>1.92>1.81$ in Phulpur for jaundice, dysentery, diarrhoea and other GI disorders respectively. In both areas, RR was higher for Jaundice despite of its fewer occurrences. Although the RR was greater for the Jaundice in both the areas however NNT was more significant for the diarrhoea in both areas (2.43 and 5.5 in Shankargarh and Phulpur, respectively). This indicates that despite of the greater risk for Jaundice new treatment was needed after every 2-5 patients suffering from diarrhoea while it was 8-13 patients in

Table 2: Pearson's correlation coefficients (r) between various water quality parameters at Shankargarh area

\begin{tabular}{|l|l|l|l|l|l|l|l|}
\hline & Turbidity & BOD & COD & TDS & Alkalinity & Hardness & Chloride \\
\hline pH & $-0.72^{*}$ & -0.56 & -0.35 & 0.56 & $0.80^{*}$ & $0.74^{*}$ & $0.82^{*}$ \\
\hline Turbidity & 1 & 0.52 & 0.64 & -0.45 & $-0.68^{*}$ & -0.65 & -0.45 \\
\hline BOD & & 1 & $0.79^{*}$ & -0.05 & -0.56 & -0.5 & -0.51 \\
\hline COD & & & 1 & -0.2 & -0.52 & -0.5 & -0.34 \\
\hline TDS & & & & 1 & 0.58 & $0.84^{*}$ & $0.74^{*}$ \\
\hline Alkalinity & & & & & 1 & $0.85^{*}$ & $0.84^{*}$ \\
\hline Hardness & & & & & & 1 & $0.91^{*}$ \\
\hline Chloride & & & & & & & 1 \\
\hline *significant at $\mathrm{p}<0.05$ & & & & & & \\
\hline
\end{tabular}

Table 3: Pearson's correlation coefficients (r) between various water quality parameters in the Phulpur area

\begin{tabular}{|l|l|l|l|l|l|l|l|l|}
\hline & pH & Turbidity & BOD & COD & TDS & Alkalinity & Hardness & Chloride \\
\hline $\mathbf{p H}$ & 1 & -0.22 & -0.21 & 0.48 & 0.5 & -0.41 & -0.61 & -0.18 \\
\hline Turbidity & 1 & $0.87^{*}$ & -0.1 & 0.48 & $-0.80^{*}$ & 0.28 & $0.75^{*}$ \\
\hline BOD & & & 1 & 0.1 & 0.65 & 0.48 & 0.46 & 0.57 \\
\hline COD & & & 1 & -0.41 & -0.53 & 0.49 & $0.82^{*}$ \\
\hline TDS & & & & 1 & -0.14 & 0.18 & -0.68 \\
\hline Alkalinity & & & & & 1 & 0.32 & 0.3 \\
\hline Hardness & & & & & & 1 & 0.48 \\
\hline Chloride & & & & & & & 1 \\
\hline *significant at $\mathrm{p}<0.05$ & & & & & & \\
\hline
\end{tabular}

Table 4: Average number of cases of waterborne diseases reported in the inhabitants of the selected area.

\begin{tabular}{|c|c|c|c|c|c|c|}
\hline \multirow[t]{2}{*}{ S. N. } & \multirow[t]{2}{*}{ Ailments } & \multicolumn{2}{|c|}{$\begin{array}{l}\text { Number of cases } \\
\text { reported } \\
\text { (secondary data } \\
\text { sources) }\end{array}$} & \multicolumn{3}{|c|}{$\begin{array}{l}\text { Number of cases reported } \\
\text { (primary data sources) }\end{array}$} \\
\hline & & Shankargarh & Phulpur & Shankargarh & Phulpur & Unexposed area \\
\hline 1 & Diarrhoea & 50 & 40 & 40 & 20 & 8 \\
\hline 2 & Dysentery & 26 & 19 & 16 & 9 & 3 \\
\hline 3 & Jaundice & 22 & 16 & 8 & 4 & 1 \\
\hline \multirow[t]{3}{*}{4} & $\begin{array}{l}\text { Other GI } \\
\text { disorders } \\
\text { (abdominal } \\
\text { pain, } \\
\text { colitis, liver } \\
\text { inflammation } \\
\text { and vomiting } \\
\text { etc.) }\end{array}$ & 66 & 46 & 10 & 11 & 5 \\
\hline & & & & $\begin{array}{l}\text { No } \\
\text { disease }=24\end{array}$ & $\begin{array}{l}\text { No } \\
\text { disease }=26\end{array}$ & No disease $=33$ \\
\hline & & & Total & 100 & 80 & 50 \\
\hline
\end{tabular}

Secondary data were collected from primary health care centers of the selected areas, primary data were

Collected by field survey

jaundice. Other GI disorders needed more rigorous (NNT-9.29) treatment in Phulpur compared to jaundice (NNT-13.67) though the RR was far greater for jaundice (3.48) than other GI disorders (1.81) (Table 5).

\section{Discussion}

The present study revealed that there was a mixed evidence of degradation in ground water quality in both the selected areas of trans-Ganga and Yamuna. In these areas, majority of villages have sources of contaminated water characterized by physico-chemical and/or biological contamination which leads to emergence of various ailments in rural population, specifically associated to metabolic disorders like gastroenteritis. The prevalence of waterborne diseases was higher in Shankargarh area in comparison to Phulpur area, and this could be due to 
Table 5: Comparative assessment of relative risk (RR), 95\% confidence interval (CI), Z-stat, significance level and number needed to treat (NNT) of the waterborne diseases in the trans-Yamuna (Shankargarh) and trans-Ganga (Phulpur) area.

\begin{tabular}{|c|c|c|c|c|c|c|c|c|c|c|}
\hline \multicolumn{6}{|c|}{ Shankargarh area } & \multicolumn{5}{|c|}{ Phulpur area } \\
\hline Diseases & $\mathbf{R R}$ & $95 \% \mathrm{CI}$ & Z -stat & $\begin{array}{l}\text { Significance } \\
\text { level (p) }\end{array}$ & $\begin{array}{l}\text { NNT } \\
\text { (benefit) }\end{array}$ & $\mathbf{R R}$ & $95 \% \mathrm{CI}$ & Z -stat & $\begin{array}{l}\text { Significance } \\
\text { level (p) }\end{array}$ & $\begin{array}{l}\text { NNT } \\
\text { (benefit) }\end{array}$ \\
\hline Diarrhoea & 3.11 & $1.61-5.95$ & 3.42 & 0.0006 & 2.43 & 1.92 & $0.94-3.90$ & 1.8 & 0.07 & 5.5 \\
\hline Dysentery & 4.57 & $1.44-14.43$ & 2.59 & 0.009 & 3.36 & 2.45 & $0.71-8.39$ & 1.43 & 0.15 & 8.25 \\
\hline Jaundice & 8 & $1.05-60.53$ & 2.01 & 0.04 & 4.85 & 3.48 & $0.40-29.71$ & 1.14 & 0.25 & 13.67 \\
\hline $\begin{array}{l}\text { Other GI } \\
\text { disorders }\end{array}$ & 2.11 & $0.79-5.5$ & 1.5 & 0.13 & 6.84 & 1.81 & $0.69-4.77$ & 1.21 & 0.22 & 9.29 \\
\hline
\end{tabular}

the more contamination in ground water and its intake owing to the geography of the area (soil characteristic and vegetation), intense anthropogenic activities, poor awareness on use of safe drinking water and limited sources of potable water in the rural environs. The geographical state of Shankargarh region is hilly, hence soil characteristic is porous, therefore surface water runoff easily seeped into underground aquifers or paleochannels [30]. This thorough flow system of surface water is due to poor and scattered vegetation, because natural floral filtration membrane couldn't be formed easily in this region. In contrast, Phulpur section has a dense cover of vegetation, thus forming a natural sieve for water filtration before seepage or recharge into underground water. The plants diversity found in this area have ability to absorb the contamination intermingled with rain water and surface runoff. In Phulpur area, there are intense networks of palaeo-channels, and these were developed due to change of river course in the Gangetic basin [31,32]; and these channels are interlinked to each other [33]. Also, these paleo-channels are the main source of underground freshwater which is easily available for the rural and sub-urban population [31]. Therefore, natural water contamination like $\mathrm{pH}$, TDS, alkalinity, hardness and chloride were found in limited number of water samples in this area. In Shankargarh area, palaeo-channels are almost absent, but underground fresh water is stored in small aquifers during monsoon season, and these aquifers are in direct contact to different kinds of rocks, releasing specific types of minerals which may cause natural contaminations like fluoride, iron, hardness, TDS, arsenic etc [34]. Since, Shankargarh area is a hilly terrain area, therefore underground rocks may be releasing their minerals in the aquifers, thus alkalinity, hardness and chloride were found in large number of water samples, above the BIS limit in this area (Figure 2A). Some other water quality parameters were also higher in Shankargarh area than Phulpur (Figure 2A \& $2 \mathrm{~B}$ ) indicating that the underground water of the trans-Yamuna region is more degraded as compared to the trans-Ganga region.

Almost all villages are facing some kind of problems in water quality in Shankargarh area in which increased turbidity and chloride content is of greater concern. However, very high hardness and alkalinity in some villages is also alarming. The significant associations of several water quality parameters with the TDS indicate that the dissolved matters were the most important contaminants for the ground water in the Shankargarh area than Phulpur (Figure 2, Table 4). The turbidity was found alarmingly high in $22 \%$ samples of Shankargarh area. It may be due to microbial contamination as turbidity depends on the refractive index of the water samples which is a depiction of contamination of water in proportion to the suspended particles or even microorganisms [35].The high turbidity may be attributed to larger particles such as organic matter and dissolved solids. Sometimes the excess of fertilizer use also increases the turbidity of ground water [36]. The high values in TDS and turbidity were obtained at sites close to the mining areas or disturbed or denuded vegetation patches. Excess of chloride salts in ground water of Shankargarh was found and which was correlated with TDS, alkalinity and Hardness. This suggests that the sources of chloride are coming from dissolved solids and they are also increasing the hardness and alkalinity. The cause of alkalinity is the minerals which dissolve in water from soil such as carbonate, bicarbonate, hydroxide, phosphate, borate and organic acids etc [17]. It is expected that these salts are causing more alkalinity in drinking water of this area are coming from some same kind of sources and getting mixed with runoff and reaching to the ground water through seepage and other such processes. The soil porosity and permeability also have a key role in increasing the chemical concentration in ground water [15]. COD determines the oxygen consuming potential of a water resource. The BIS has stipulated 8 $\mathrm{mg} \mathrm{L}^{-1}$ standard for COD for safe drinking water [29]. All samples collected had less COD in both areas indicating less contamination of nitrogenous wastes in open wells that could lead to higher COD values. The water samples of Chandra, Bara Tehseel and Gurme Bara of trans-Yamuna region are having much hardness (Figure 2A). This may cause various heart ailments if are used for a long time as there are reports which relate the heart ailments with the long time consumption of hard water $[37,38]$. The mining operation in these areas may be the significant cause of water hardness as well as the other water quality disturbances while any such mining activity is not prevailing in the Phulpur area. Other studies also report the effect of mining on ground water pollution and associated health impacts [7, 39, 40, 41].

The waters of trans-Ganga (Phulpur) area were found almost safe as many parameters were well within the permissible limits of [29]. Except in few villages, the turbidity and TDS was in normal limits in this area (Figure 2B) .There are reports on degrading ground water quality from other north Indian states 
as well which support the findings of this study $[4,6,12,35,42]$. However, these kinds of report from the study area are sporadic and most of them only concentrated on the assessment of water qualities only without taking note of associated health effects [16].

The disease occurrence reported in this area corresponds to the degraded quality of the water samples tested (Table 4 and 5). It is quite clear that the Shankrgarh area has more degradation in water quality (Figure 2A) as compared to Phulpur (Figure 2B) and in concurrence with that more disease were reported in the Shankargarh area which are waterborne diseases. There are many studies depicting the relation between ground water quality and the disease occurrence however, these are sporadic from the study area [14, 15, 30, 43]. Further, increased contamination of fecal coliform in water samples in Shankargarh as comperd to Phulpur (Figure 3A \& 3B) clearly indicates that the underground water samples of Shankargarh appear to pose more of a human health risk as compared to Phulpur area. This is due to the fact that owing to unhealthy sanitation conditions microbes found in dung and excreta get mixed with the runoff water in rainy season and find a way to ground water due to open bore wells and well waters or due to drill holes of tube wells and other such places which have direct contact to ground water [20]. This also increases the turbidity and TDS in water and thereby disturbs other water quality parameters depending upon the amount and physico-chemical nature of the contaminants mixed $[19,44]$. The increased level of TDS and turbidity in villages of Shankargarh area corresponds to this fact. The lack of a safe water supply in the study area forces villagers to depend on the groundwater as their primary source of drinking and household water.

The statistical results of the relative risk assessment for waterborne diseases are presented in Table 5. The Relative Risk values (RR) for both the areas were high and Jaundice had maximum RR which means that in both the areas despite of its fewer occurrences as compared to other disease reported the people are on high risk to fell ill by jaundice. A high level of RR corresponds to a high human health threat $[38,40]$. Risk values $\mathrm{RR}>1$ indicate the potential adverse effects and the need to improve groundwater quality. Further, the NNT parameter is more significant for the diarrhoea in both areas (Table 5). This indicates that despite of the greater risk for Jaundice in both the sampling areas; new treatment (other than standard) is needed for diarrhea after every 2-5 patients suffering from it. It indicates that while jaundice can be treated with standard methods of the treatment however, diarrhoea needs better and advance treatment frequently. This kind of information is needed in such cases as it has also been used in some other countries in waterborne diseases [45]. Certain measures, such as controlling pollution and lowering TDS and turbidity levels in groundwater must be employed to reduce health risks by fecal coliform. Though, the ingestion was considered as the main exposure route in this study, other possible pathways include inhalation and through ingestion of food washed with contaminated water [40]. The estimated water quality in trans-Ganga area was relatively safer in terms of physico-chemical water quality parameters than Trans-Yamuna; however RR value was higher $(>1)$ in both the areas. This indicates that occurrence of diseases reported from these areas is also dependent on the fecal pollution of ground waters. This stimulates need of water quality and health facility improvements in both the areas by clearly emphasizing the kind of treatment are to be needed and which disease needs more attention in which area.

\section{Conclusion}

The results clearly suggest that the ground water of the rural trans-Yamuna region of Allahabad district is highly degraded as compared to the trans-Ganga area. Increasing cases of waterborne diseases were reported from both areas higher being in transYamuna area. Jaundice and diarrhea seems the significant health hazards in both the areas with higher health risks are posed in trans-Yamuna area as compared to trans-Ganga. A government intervention to ensure potable quality of water is these rural areas is needed with giving more emphasis to Shankargarh (trans-Yamuna) region. Continuous monitoring with seasonal variability and intensive health studies are recommended in order to determine the other pollutants and disease occurrence to ascertain long-term effects. A thorough understanding of the fecal pollution sources affecting the rural groundwater quality is also necessary to improve and manage water quality degradation in these areas.

\section{Acknowledgements}

The authors are grateful to National Council of Science \& Technology Communication (NCSTC), DST, New Delhi (Project No CO/FP/C11/09) for financial support. The authors are thankful to the President, Institute of Applied Sciences (IASc) for providing laboratory facilities and institutional support.

\section{References}

1. Tripathi M, Srivastava VC. Impact of safe water on national health profile Book Water (Ensuring Safety \& Management), Edited by Dr. A. F. Rizvi \& Ms. Archna Pant. 2010;12-22.

2. Tripathi A, Misra DR. A study of physico-chemical properties and heavy metals in contaminated soils of municipal waste dumpsites at Allahabad, India. International Journal of Environmental Science. 2012;2(4): 20-24.

3. Addo MA, Darko EO, Gordon C, B. J. B. Nyarko. Water quality analysis and human health risk assessment of groundwater from openwells in the vicinity of a cement factory at Akporkloe, Southeastern Ghana. 2013;4:8.

4. Pathak H, Limaye SN. Assessment of physico-chemical quality of ground water in rural area nearby Sagar city, M.P., India. Advances in Applied Science Research. 2012;3(1):555-562.

5. Serveiss VB, Ohlson DW. Using ecological risk assessment principles in a source water protection assessment. Human Ecological Risk Assessment. 2007;13(2):402-417.

6. Meesum SAM, Masood M, Rizvi AF. Impact of waterbornee diseases on health. Book Water (Ensuring Safety \& Management), Edited by Dr. A.F. Rizvi \& Ms. Archna Pant. 2010;23-31.

7. Lu SY, Zhang HM, Sojinu SO. Trace elements contamination and human health risk assessment in drinking water from Shenzhen, China. Environ Monit Assess. 2015;187(1):4220. doi: 10.1007/ s10661-014-4220-9. 
8. Gaffney deJV, Almeida CM, Rodrigues A. Occurrence of pharmaceuticals in a water supply system and related human health risk assessment. Water Res. 2015;72:199-208. doi: 10.1016/j.watres.2014.10.027.

9. Chakraborti D, Rahman MM, Ahamed S. Arsenic contamination of groundwater and its induced health effects in Shahpur block, Bhojpur district, Bihar state, India: risk evaluation. Environ Sci Pollut Res Int 2016;23(10):9492-504. doi: 10.1007/s11356-016-6149-8.

10. Naz A, Chowdhury A, Mishra BK. et al. Metal pollution in water environment and the associated human health risk from drinking water: A case study of Sukinda chromite mine, India. Human Ecological Risk Assessment. 2016;22(7):1433-1455. DOI:10.1080/10807039.2 016.1185355

11. Venkateswara BR. Physico-chemical analysis of selected ground water samples of Vijayawada rural and urban in Krishna district, Andhra Pradesh, India. International Journal of Environmental Science. 2011;2(2):722-726.

12. Dixit SK, Tiwari AK, Chaturvedi SK. Preliminary Investigations of Ground Water Quality in Rural Areas of Karwi, Chitrakoot. Research Journal on Science and Technology. 2015;7(3):176.

13. Jain PK. Hydrology and quality of groundwater around Hirapur district, Sagar (M.P.)- A case study of protozoic rocks. Pollution Research. 1998;17(1):91-94.

14. Çelebi A, Șengörür B, Kløve B. Human health risk assessment of dissolved metals in groundwater and surface waters in the Melen watershed, Turkey. Journal of Environmental Science and Health 2014;49(2):153-161.

15. Huang B, Li Z, Chen Z. Study and health risk assessment of the occurrence of iron and manganese in groundwater at the terminal of the Xiangjiang River. Environmental Science Pollution Research. Environ Sci Pollut Res Int. 2015;22(24):19912-21. doi: 10.1007/s11356-0155230-z.

16. Mittal A, Kumar M. Ground Water Status-A Case Study of Allahabad, UP, India. International Journal of Advance Engineering and Technology. 2014;7(3):838.

17. Prüss-Ustün A, Bartram J, Clasen T. Burden of disease from inadequate water, sanitation and hygiene in low-and middle-income settings: a retrospective analysis of data from 145 countries. Trop Med Int Health. 2014;19(8):894-905. doi: 10.1111/tmi.12329.

18. Kirs M, Harwood VJ, Fidler AE. Source tracking faecal contamination in an urbanised and a rural waterway in the Nelson-Tasman region, New Zealand. New Zealand. Journal of Marine and Freshwater Research. 2011; 45(1):43-58.

19. Dufour AP. Escherichia coli: the fecal coliform. In Bacterial indicators/ health hazards associated with water. ASTM International. 1977. doi: 10.1520/STP34817S

20. Fong TT, Lipp EK. Enteric viruses of humans and animals in aquatic environments: health risks, detection, and potential water quality assessment tools. Microbiological and Molecular Biology Revisited. 2005; 69(2):357-371. doi: 10.1128/MMBR.69.2.357-371.2005.

21. Tripathi A, Singh GS. Perception, anticipation and responses of people to changing climate in the Gangetic Plain of India. Current Science. 2013;105(12):1673-83.

22.Tripathi A, Tripathi DK, Chauhan DK. Chromium (VI)-induced phytotoxicity in river catchment agriculture: evidence from physiological, biochemical and anatomical alterations in Cucumis sativus (L.) used as model species. Chemistry and Ecology. 2015;32(1):12-33. doi: 10.1080/02757540.2015.1115841.
23. Bhargava DS. Most rapid BOD assimilation in Ganga and Yamuna rivers. Journal of Environmental Engineering. 1983;109(1):174-188.

24. Singh S, Srivastava RK. Geology of Allahabad (India) and Assessment of Recharge for Sustainability. Proceedings of Indian Geotechnical Conference December. 2011;15-17.

25.APHA. Standard methods. 19th Edition. American Public Health Association, Washington, DC. 1995

26. USEPA. Standard Methods for the Examination of Water and Wastewater, 9222 B and 9221 B. Method.

27. Altman DG. Practical statistics for medical research. London: Chapman and Hall. 1991.

28. Altman DG, 1998. Confidence intervals for the number needed to treat. BMJ. 1998 Nov 7;317(7168): 1309-1312.

29. BIS. Indian standard drinking water - specification (First Revision) IS10500:1991. BIS, New Delhi, India. 1991.

30. Chaturvedi R. Application of Remote Sensing a GIS in Land Use/ Land Covers Mapping in Allahabad District. International Journal of Advance Engineering and Technology. 2014;1(4).

31. Pati JK, Malviya VP, Prakash K. Basement reactivation and its relation to Neotectonic activity in and around Allahabad, Ganga plain. Journal of Indian Society of Remote Sensing. 2006;34(1):47-56. doi:10.1007/ BF02990746.

32. Singh SK, Srivastava PK, Singh D. Modeling groundwater quality over a humid subtropical region using numerical indices, earth observation datasets, and X-ray diffraction technique: a case study of Allahabad district, India. Environmental and Geochemical Health. 2015;37(1):157-180. doi:10.1007/s10653-014-9638-z.

33. Gautam AM. Application of IRS-1A data for delineating buried channels in southern part of Allahabad district of Uttar Pradesh. Journal of Indian Society of Remote Sensing. 1990;18(3):52-55.

34. Aral MM, Guan J, Maslia ML. Identification of contaminant source location and release history in aquifers. Journal of Hydrological Engineering. 2001;6(3):225-234

35. Garg VKS, Suthar S, Singh A. Drinking water quality in villages of southwestern Haryana, India: assessing human health risks associated with hydrochemistry. Environmental Geology. 2009;58(6):1329-1340.

36. Singh B, Singh Y, Sekhon GS. Fertilizer-N use efficiency and nitrates pollution of ground water in developing countries. Journal of Contaminant Hydrology. 1995;20(3-4):167-184.

37. Schroeder HA. Relations between hardness of water and death rates from certain chronic and degenerative diseases in the United States. Journal of Chronic Diseases. 1960;12(6):586-591.

38. Prüss A, Kay D, Fewtrell L. Estimating the burden of disease from water, sanitation, and hygiene at a global level. Environmental Health Perspectives. Environ Health Perspect. 2002;110(5):537-542.

39. Xin L. Research of impact of waste dump of open pit coal mining on ground water environmental quality. Opencast Coal Mining Technology 2:001. 2002.

40. Rai S, Gupta S, Mittal PC. Dietary Intakes and Health Risk of Toxic and Essential Heavy Metals through the Food Chain in Agricultural, Industrial, and Coal Mining Areas of Northern India. Human Ecological Risk Assessment. 2015; 21(4):913-933. 10.1080/10807039.2014.946337.

41. Singh G, Kamal RK. Assessment of groundwater quality in the mining areas of Goa, India. Indian Journal of Science and 
Technology. 2015;8(6):588-595. doi: 10.17485/ijst/2015/ v8i6/62314

42. Pandey R, Pandey SK. Investigations of physico-chemical status of ground water of Singrauli District, Madhya Pradesh, India. International Journal of Pharmaceutical Science and Research. 2012;3(10):3823-3828.

43. Giri S, Singh AK. Human health risk assessment via drinking water pathway due to metal contamination in the groundwater of Subarnarekha River Basin, India. Environ Monit Assess.
2015;187(3):63. doi: 10.1007/s10661-015-4265-4.

44. Jaipieam S, Visuthismajarn P, Sutheravut P. Organophosphate pesticide residues in drinking water from artesian wells and health risk assessment of agricultural communities, Thailand. Human Ecological Risk Assessment. 2009;15(6):1304-1316. doi: $10.1080 / 10807030903306984$.

45. Elko L, Rosenbach K, Sinnott J. Cutaneous manifestations of waterborne infections. Current Infectious Disease Reports. 2003;5(5):398-406. 